\title{
INHIBITION OF ANGIOGENESIS BY ERBSTATIN, AN INHIBITOR OF TYROSINE KINASE
}

\author{
Tsutomu Oikawa, Hiromi Ashino and Mariko Shimamura
}

Division of Cancer Therapeutics, The Tokyo Metropolitan Institute of Medical Science, 3-18-22 Honkomagome, Bunkyo-ku, Tokyo 113

Masami Hasegawa, Ikuo Morita and Sei-itsu Murota

Tokyo Medical and Dental University, 1-5-45 Yushima, Bunkyo-ku, Tokyo 113, Japan

\section{MASAAKI ISHIZUKA}

Institute for Chemotherapy, Microbial Chemistry Research Foundation, 18-24 Aza-motono, Miyamoto, Numazu-shi, Shizuoka 410-03, Japan

\section{TOMIO TAKEUCHI}

Institute of Microbial Chemistry, Microbial Chemistry Research Foundation, 3-14-23 Kamiosaki, Shinagawa-ku, Tokyo 141, Japan

(Received for publication January 19, 1993)

\begin{abstract}
Here we describe the inhibitory effect of erbstatin, a specific tyrosine kinase inhibitor, on in vivo angiogenesis. Inhibition of angiogenesis was determined in a bioassay system involving chorioallantoic membranes of growing chick embryos. Erbstatin produced a dose-dependent inhibitory action on embryonic angiogenesis. This inhibition occurred at as small a dose as $10 \mathrm{ng} / \mathrm{egg}$ and the ID 50 value was $80 \mathrm{ng} / \mathrm{egg}$. To analyze this inhibition, in vitro experiments involving vascular endothelial cells were also performed. Erbstatin affected the proliferation of vascular endothelial cells, one of angiogenic components. This inhibition was dose-dependent, the $\mathrm{IC}_{50}$ value being $3.6 \mu \mathrm{M}$. These data indicate that erbstatin-sensitive tyrosine kinase(s) is involved in angiogenic endothelial cell proliferation, and that experiments involving erbstatin will provide an important clue to understand a mechanism of angiogenesis.
\end{abstract}

It is widely accepted that angiogenesis is a key factor in the progression of malignant tumors. Evidence has been accumulating that a variety of growth factors induce an angiogenic response is in vivo assay systems involving rabbit cornea or chick embryo chorioallantoic membrane (CAM). These angiogenic mitogens include acidic and basic fibroblast growth factors, epidermal growth factor (EGF), vascular endothelial growth factor and hepatocyte growth factor ${ }^{1}{ }^{4)}$. Interestingly, their respective receptors have been found to show tyrosine kinase activity ${ }^{4}$ ), suggesting that tyrosine phosphorylation might be an important signal in the angiogenesis process. In relation to this, it was interesting that phosphotyrosine-modified proteins were concentrated at the cell-to-cell adherens junctions in vascular endothelial cells of various tissues during chick embryo development and that specific proto-oncogenic tyrosine kinases of the $\operatorname{src}$ family were enriched in the cell-to-cell adherens junctions ${ }^{8,9}$. In addition, vanadate, a specific inhibitor of phosphotyrosine phosphatase, promotes vascular endothelial cells to form vessel-like tubules and also to produce two types of plasminogen activators, proteolytic enzymes known to be involved in an angiogenic response ${ }^{10}$. 
We found recently that staurosporine, isolated from a strain of Streptomyces, inhibits in vivo angiogenesis in the picomolar range of dose ${ }^{11)}$. Because this microbial product was originally identified as a potent protein kinase $\mathrm{C}$ inhibitor ${ }^{12)}$, it was suggested that it might elicit its antiangiogenic action by inhibiting kinase activity. In addition to this inhibitory activity, staurosporine was also found to inhibit tyrosine kinase and cAMP-dependent protein kinase within a similar range of concentrations to that required for inhibition of protein kinase $\mathrm{C}^{13)}$. Thus it might be also possible that the antiangiogenic action of staurosporine is associated with the inhibition of tyrosine kinase or cAMP-dependent protein kinase or both. Specific inhibitors of protein kinase C, tyrosine kinase or cAMP-dependent protein kinase should provide a clue to this problem.

Erbstatin was isolated from the culture filtrate of a strain of Streptomyces as an inhibitor of tyrosine kinase activity of the EGF receptor ${ }^{14)}$. It also inhibits the activity of the $s r c$ tyrosine kinase, but dose not inhibit cAMP-dependent protein kinase or protein kinase $\mathrm{C}^{15}$, implying that erbstatin, unlike staurosporine, is a specific inhibitor of tyrosine kinase.

Here we show that erbstatin dose-dependently exerts an angiogenesis-inhibitory effect in an in vivo assay system involving growing chick embryo CAM. In vitro experiments revealed that erbstatin also inhibits the proliferation of vascular endothelial cells in a concentration-dependent manner. These findings indicate the possibility that tyrosine kinase plays a role in vascular endothelial cell growth, a crucial component of the angiogenesis process, and that erbstatin evokes an antiangiogenic action, probably through inhibition of the tyrosine kinase activity.

\section{Materials and Methods}

Chemicals

Erbstatin was isolated as described previously ${ }^{14)}$. Ethylene-vinyl acetate copolymer 40 (EV 40) was a generous gift from Mitsui-DuPont Polychemical Co., Ltd., Tokyo, Japan. EV 40 was used in the present study, after being fully washed in an excess of $99 \%$ ethanol to remove impurities affecting the CAM assay. DulbeCCo's modified EAGLE's medium (DMEM) was a product of Sigma Chemical Co., St. Louis, MO. Fetal bovine serum (FBS) was obtained from Biocell Lab., Carson, CA and a mixture of penicillinstreptomycin from Gibco Lab., Grand Island, NY.

\section{Preparation of EV 40 Pellets Containing Erbstatin}

Erbstatin was dissolved in ethanol at a concentration of $1 \mathrm{mg} / \mathrm{ml}$, sequentially diluted with ethanol and then mixed with an equal volume of $5 \%$ EV 40 dissolved in methylene chloride. Aliquots $(20 \mu 1)$ of a mixture were dropped on sterilized glass plates and then air-dried. Dried films of EV 40 were made into pellets using a microspatula and stored at $-40^{\circ} \mathrm{C}$ until used.

\section{Assay of Antiangiogenic Activity in CAM}

Inhibition of angiogenesis was determined in a bioassay system involving CAMs of growing chick embryos as described ${ }^{16)}$. An EV 40 pellet containing the indicated dose of erbstatin was placed carefully on the CAM surface of 4.5-day-old chick embryo and then incubated in a humidified egg incubator. After 2 days of incubation, an appropriate volume of $20 \%$ fat emulsion was injected into the chorioallantois to improve visualization of the vascular network. Inhibition of angiogenesis was assessed by measuring the avascular zone in the CAM. An antiangiogenic response was assessed as effective when the avascular zone exceeded $3 \mathrm{~mm}$.

Assay of Vascular Endothelial Cell Proliferation

Vascular endothelial cells were prepared and maintained in basal medium (DMEM containing $25 \mathrm{mM}$ 
Hepes, 100 units $/ \mathrm{ml}$ benzylpenicillin and $100 \mu \mathrm{g} / \mathrm{ml}$ streptomycin) supplemented with $10 \%$ FBS, as described previously ${ }^{11,17)}$. Endothelial cells $\left(5 \times 10^{3}\right.$ cell/well) were plated into the wells of 24 -multiwell dishes (Falcon; Becton Dickinson Co., Lincoln, NJ) containing $1 \mathrm{ml}$ of basal medium supplemented with $5 \%$ FBS. Five hours after plating of the cells, aliquots $(20 \mu \mathrm{l})$ of various concentrations of erbstatin dissolved in $5 \%$ ethanol-basal medium were added directly into the medium, where the final concentration of ethanol was identical in all wells and was $0.1 \%$. After 72 -hours incubation at $37^{\circ} \mathrm{C}$ under an atmosphere of $5 \% \mathrm{CO}_{2}$ in air, the cells were trypsinized and then counted in a Coulter counter ZBI (Coulter Electronics Inc., Hialeah, FL).

\section{Statistical Analysis}

Data as to the incidence of antiangiogenic activity were analyzed by means of FISHER's exact probability test, $p<0.05$ being taken as the level of significance. Results as to the endothelial cell proliferation were analyzed by means of STUDENT's $t$-test with $p<0.05$ as the level of significance.

\section{Results}

\section{Antiangiogenic Effect of Erbstatin}

Erbstatin was examined for its antiangiogenic effect in the CAM assay system. Fig. 1 represents the dose-response relationship for the appearance of an avascular zone. Erbstatin inhibited the embryonic angiogenesis dose-dependently. In comparison with the effects of empty EV pellets (control) which did not cause inhibition of embryonic angiogenesis in any of $20 \mathrm{CAMs}$ examined, the minimum effective dose required for causing an avascular zone was $10 \mathrm{ng}$ ( $56 \mathrm{pmol})$ per egg, and the $\mathrm{ID}_{\text {so }}$ value was $80 \mathrm{ng} / \mathrm{egg}$. Representatives of these experiments are shown in Fig. 2. Erbstatin effectively inhibited embryonic angiogenesis to cause a significant avascular zone, while an EV pellet alone did not elicit such an action in any of the CAMs treated.
Fig. 1. Inhibitory effect of erbstatin on embryonic angiogenesis.

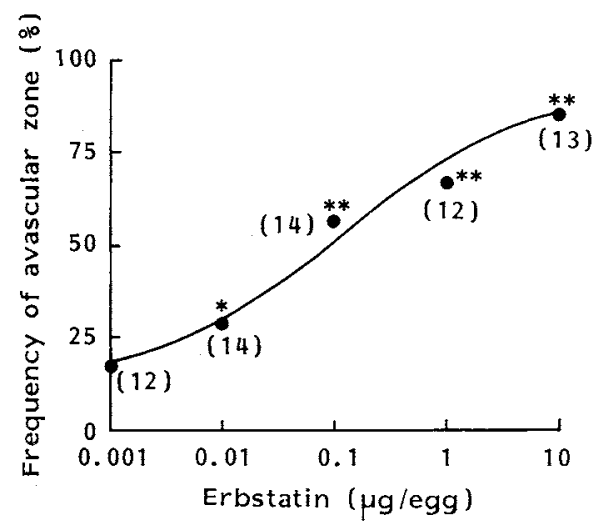

After EV pellets containing various doses of erbstatin were placed on the 4.5-day-old CAM, the antiangiogenic activity was assessed as described in Materials and Methods. The values in parentheses show the number of CAMs used. ${ }^{*} P<0.05$ compared to empty pellet-treated (i.e., control) CAMs $(\mathrm{n}=20)$ which did not cause antiangiogenic activity; ${ }^{* *} P<$ 0.001 compared to the control.

Fig. 2. Effect of erbstatin on angiogenesis in CAM 2 days after placement of EV pellets with erbstatin (A, $0 \mathrm{ng} /$ pellet; $\mathrm{B}, 100 \mathrm{ng} /$ pellet).

(A)

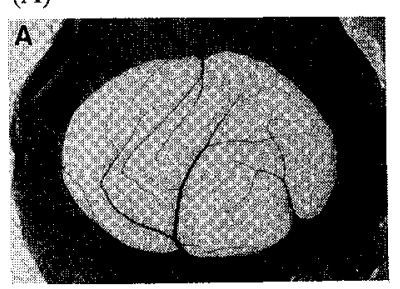

(B)

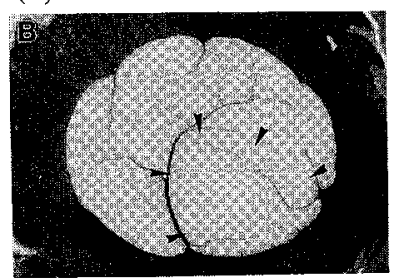

EV pellets with erbstatin caused an avascular zone (surrounded with arrows) showing antiangiogenic activity, while empty pellets without the agent did not. Magnification, $\times 1.6$. 
Effect of Erbstatin on Proliferation of

Vascular Endothelial Cells

To find a clue to the understanding of a mechanism of angiogenesis inhibition by erbstatin, in vitro experiments were carried out to determine whether or not the microbial product affected proliferation of vascular endothelial cells, a key step in the angiogenesis process. It exerted an inhibitory effect on the endothelial cell proliferation in a concentration-dependent manner, the $\mathrm{IC}_{50}$ being $3.6 \mu \mathrm{M}$.

\section{Discussion}

Angiogenesis has become an attractive target of studies on cancer treatment, because different types of angiogenesis inhibitors have been proven effective in growth inhibition of solid tumors ${ }^{18 \sim 23)}$ However, the molecular bases of angiogenesis have not yet been well understood. An angiogenesis inhibitor with an unique mode of action seems to give us useful information to approach this important problem.

Our previous study showed that staurosporine affects in vivo angiogenesis, the $\mathrm{ID}_{50}$ value being $71 \mathrm{pmol} / \mathrm{egg}^{11)}$. This indicated that certain protein kinases, including protein kinase $\mathrm{C}$, tyrosine kinase and cAMP-dependent protein kinase, might play a crucial role in induction of angiogenesis, because staurosporine exerts potent inhibitory effects on different protein kinases in a similar concentration range ${ }^{13)}$. Thus, which type(s) of protein kinase is associated with angiogenesis induction remains to be clarified. To approach this problem, in this study we examined the effect of erbstatin, a specific inhibitor of tyrosine kinase, on angiogenesis in the CAM assay, and found that it is an effective inhibitor of angiogenesis. Taking the present result together with our previous observation that herbimycin A, another specific tyrosine kinase inhibitor, effectively inhibits angiogenesis ${ }^{24)}$, it is conceivable to assue that certain tyrosine kinase plays a role in induction of angiogenesis in vivo.

When compared on a molar basis, erbstatin appears to be weaker in antiangiogenic ability $\left(\mathrm{ID}_{50}=\right.$ $450 \mathrm{pmol} / \mathrm{egg})$ than a synthetic retinoid $\mathrm{Ch} 55\left(\mathrm{ID}_{50}=24 \mathrm{pmol} / \mathrm{egg}\right), 22$-oxa- $1 \alpha, 25$-dihydroxyvitamin $\mathrm{D}_{3}$ $\left(\mathrm{ID}_{50}=96 \mathrm{pmol} / \mathrm{egg}\right)$, staurosporine $\left(\mathrm{ID}_{50}=71 \mathrm{pmol} / \mathrm{egg}\right)$ and eponemycin $\left(\mathrm{ID}_{50}=250 \mathrm{fmol} / \mathrm{egg}\right)^{11,16,25,26)}$. On the other hand, erbstatin seems to exert similar antiangiogenic effect as herbimycin $\mathrm{A}\left(\mathrm{ID}_{50}=\right.$ $260 \mathrm{pmol} / \mathrm{egg}$ ), retinoic acid $\left(\mathrm{ID}_{50}=330 \mathrm{pmol} / \mathrm{egg}\right)$ and $1 \alpha, 25$-dihydroxyvitamin $\mathrm{D}_{3} \quad\left(\mathrm{ID}_{50}=340 \mathrm{pmol} /\right.$ egg ${ }^{16,24,26)}$. Taking these findings together, erbstatin seems to be a moderate angiogenesis inhibitor.

We would like to discuss the question that what kind of tyrosine kinase is inhibited by erbstatin. Erbstatin was originally identified as an inhibitor of tyrosine kinase activity of the receptor of EGF, known to be an inducer of angiogenesis, although it exerts an inhibitory effect on neither protein kinase $\mathrm{C}$ nor cAMP-dependent protein kinase. It also inhibited the $\operatorname{src}$ tyrosine kinase ${ }^{14,27)}$, as did herbimycin $\mathrm{A}^{28)}$. In addition, there are interesting findings that phosphotyrosine-modified proteins were found to be concentrated at the cell-to-cell adherens junctions in various tissues during development of chick embryo and the members of the $s r c$ family, including c-src and c-yes tyrosine kinases, were enriched in the cell-to-cell adherens junctions ${ }^{8,9)}$. Considering these findings, the $s r c$ tyrosine kinase or its related tyrosine kinase would be a promising candidate of targets of erbstatin. It might also be possible that the tyrosine kinase of the receptors of a variety of putative angiogenic factors, including EGF, fibroblast growth factor, vascular endothelial growth factor and hepatocyte growth factor, might be susceptible to erbstatin, because their growth factors contain a tyrosine kinase domain ${ }^{4} \sim 7$ ).

Previous study showed that erbstatin inhibits the growth of A431 cells with an $\mathrm{IC}_{50}$ value of $20 \mu \mathrm{M}$ or IMC-carcinoma cells with an $\mathrm{IC}_{50}$ value of $17 \mu \mathrm{M}^{14)}$. Taking these findings together with the present observation that erbstatin dose-dependently inhibited proliferation of vascular endothelial cells, the $\mathrm{IC}_{50}$ 
being $3.6 \mu \mathrm{M}$, the endothelial cells seem to be more sensitive to the microbial product than these two tumor cell lines although it does not selectively inhibit the endothelial cell growth.

The present in vitro experiments involving vascular endothelial cells suggested that the cell proliferation inhibitory effect of erbstatin is probably involved in the antiangiogenic mechanism. However, this inhibitory action on the endothelial cell growth appeared less effective than those of other angiogenesis inhibitors, such as staurosporine and eponemycin ${ }^{11,25)}$, which show growth-inhibitory activity against endothelial cells. This might be in part due to the previously reported instability of erbstatin in serum ${ }^{29,30)}$. Another possibility might be that erbstatin exhibits an antiangiogenic effect through the modification of the differentiation state of angiogenic endothelial cells, taking the previous observation that the microbial product induces the change of transformed cells into morphologically normal phenotype cells ${ }^{31)}$, together with our previous findings that cell differentiation modifiers such as retinoids and vitamin $\mathrm{D}_{3}$ analogs are also effective angiogenesis inhibitors ${ }^{16,26,32}$. Further study on elucidation of the mechanism of antiangiogenic activity of erbstatin will undoubtedly provide us an important clue of better understanding of a mechanism of angiogenesis.

\section{Acknowledgments}

This work was supported in part by Grants-in-Aid for Cancer Research from the Japanese Ministry of Education, Science and Culture. We thank Dr. MaSAYa Imoto, Keio University, for his stimulating discussion.

\section{References}

1) Folkman, J. \& M. Klagsbrun: Angiogenic factors. Science 235: 442 447, 1987

2) Blood, C. H. \& B. R. ZetTeR: Tumor interactions with the vasculature and tumor metastasis. Biochim. Biophys. Acta 1032: $89 \sim 118,1990$

3) Folkman, J. \& Y. Shing: Angiogenesis. J. Biol. Chem. 267: 10931 10934, 1992

4) Bussolino, F.; M. F. Di Renzo, M. Ziche, E. Bocchietto, M. Olivero, L. Naldini, G. Baudino, L. Tamagnone, A. COFFER \& P. M. Comoglio: Hepatocyte growth factor is a potent angiogenic factor which stimulates endothelial cell motility and growth. J. Cell Biol. 119: 629 641, 1992

5) Hunter, T. \& J. A. Cooper: Protein-tyrosine kinases. Annu. Rev. Biochem. 54: 897 930, 1985

6) UlLRICH, A. \& J. SCHLESSINGER: Signal transduction by receptors with tyrosine kinase activity. Cell 61: 203 212, 1990

7) de Varies, C.; J. A. Escobedo, H. Ueno, K. Houck, N. Ferrara \& L. T. Williams: The fms-like tyrosine kinase, a receptor for vascular endothelial growth factor. Science 255: $989 \sim 991,1992$

8) Tanaka, K. \& S. J. Singer: Phosphotyrosine-modified proteins are concentrated at the membranes of epithelial and endothelial cells during tissue development in chick embryos. J. Cell Biol. 106: 1757 1764, 1988

9) Tsukita, S.; K. Oishi, T. AkiYama, Y. Yamanashi, T. Yamamoto \& S. Tsukita: Specific proto-oncogenic tyrosine kinases of src family are enriched in cell-to-cell adherens junctions where the level of tyrosine phosphorylation is elevated. J. Cell Biol. 113: 867 879, 1991

10) Montesano, R.; M. S. Pepper, D. Belin, J.-D. Vassalli \& L. OrCi: Induction of angiogenesis in vitro by vanadate, an inhibitor of phosphotyrosine phosphatases. J. Cell. Physiol. 134: 460 466, 1988

11) Orkawa, T.; M. Shimamura, H. Ashino, O. Nakamura, T. Kanayasu, I. Morita \& S. Murota: Inhibition of angiogenesis by staurosporine, a potent protein kinase inhibitor. J. Antibiotics 45: 1155 1160, 1992

12) Tamaoki, T.; H. Nomoto, I. Takahashi, Y. Kato, M. MoRimoto \& F. Tomita: Staurosporine, a potent inhibitor of phospholipid $/ \mathrm{Ca}^{++}$dependent protein kinase. Biochem. Biophys. Res. Commun. 135: 397 402, 1986

13) TAMAOKI, T:: Use of specificity of staurosporine, UCN-01, and calphostin $\mathrm{C}$ as protein kinase inhibitors. In Methods in Enzymology. Vol. 201. Eds., T. Hunter \& B. M. Sefton, pp. 340 347, Academic Press, 1991

14) Umezawa, H.; M. Imoto, T. Sawa, K. Isshiki, N. Matsuda, T. Uchida, H. Innuma, M. Hamada \& T. Takeuchi: Studies on a new epidermal growth factor-receptor kinase inhibitor, erbstatin, produced by MH435-hF3. J. Antibiotics 39: $170 \sim 173,1986$

15) Imoto, M.; K. UmezaWa, T. Sawa, T. TAKeuchi \& H. UmezaWa: In situ inhibition of tyrosine kinase by erbstatin. Biochem. Int. 15: 989 995, 1987

16) Oikawa, T.; K. Hirotani, O. Nakamura, K. Shudo, A. Hiragun \& T. Iwaguchi: A highly potent antiangiogenic activity of retinoids. Cancer Lett. 48: 157 162, 1989

17) Kanayasu, T.; J. Nakao-Hayashi, N. Asuwa, I. Morita, T. Ishil, H. Ito \& S. Murota: Leukotriene $\mathrm{C}_{4}$ stimulates angiogenesis in bovine carotid artery endothelial cells in vitro. Biochem. Biophys. Res. Commun. 159: 572 578, 1989 
18) Folkman, J.: Tumor angiogenesis. Adv. Cancer Res. 43: 175 203, 1985

19) Orkawa, T.; A. Hiragun, Y. Yoshida, H. Ashino-Fuse, T. Tominaga \& T. Iwaguchl: Angiogenic activity of rat mammary carcinoma induced by 7,12-dimethylbenz[a] anthracene and its inhibition by medroxyprogesterone acetate: possible involvement of antiangiogenic action of medroxyprogesterone acetate in its tumor growth inhibition. Cancer Lett. 43: 85 92, 1988

20) Moses, M. A. \& R. LANGER: Inhibitors of angiogenesis. Biotechnology 9: 630 634, 1991

21) Klagsbrun, M. \& P. A. D'Amore: Regulators of angiogenesis. Ann. Rev. Physiol. 53: $217 \sim 239,1991$

22) Oikawa, T; Y. Yoshida, M. Shimamura, H. Ashino-Fuse, T. Iwaguchi \& T. Tominaga: Antitumor effect of 22-oxa-1 $\alpha, 25$-dihydroxyvitamin $\mathrm{D}_{3}$, a potent angiogenesis inhibitor, on rat mammary tumors induced by 7,12 dimethylbenz[a]anthracene. Anti-Cancer Drugs 2: 475 480, 1991

23) EdGington, S. M.: Angiogenic and angiostatic drugs: Reshaping biotech's future. Biotechnology 10: $981 \sim 985,1992$

24) Oikawa, T.; K. Hirotani, M. Shimamura, H. Ashino-Fuse \& T. Iwaguchi: Powerful antiangiogenic activity of herbimycin A (named angiostatic antibiotic). J. Antibiotics 42: 1202 1204, 1989

25) Oikawa, T.; M. Hasegawa, M. Shimamura, H. Ashino, S. Murota \& I. Morita: Eponemycin, a novel antibiotic, is a highly powerful angiogenesis inhibitor. Biochem. Biophys. Res. Commun. 181: 1070 1076, 1991

26) Oikawa, T.; K. Hirotani, H. Ogasawara, T. Katayama, O. Nakamura, T. Iwaguchi \& A. Hiragun: Inhibition of angiogenesis by vitamin $\mathbf{D}_{3}$ analogues. Eur. J. Pharmacol. 178: $247 \sim 250,1990$

27) Imoto, M.; K. Umezawa, K. Isshiki, S. Kunimoto, T. Sawa, T. Takeuchi \& H. Umezawa: Kinetic studies of tyrosine kinase inhibition by erbstatin. J. Antibiotics 40: 1471 1473, 1987

28) Uehara, Y.; Y. Murakami, S. Mizuno \& S. KawaI: Inhibition of transforming activity of tyrosine kinase oncogenes by herbimycin A. Virology 164: 294 298, 1988

29) Imoto, M.; K. Umezawa, K. Komuro, T. Sawa, T. Takeuchi \& H. Umezawa: Antitumor activity of erbstatin, a tyrosine protein kinase inhibitor. Jpn. J. Cancer Res. 78: 329 332, 1987

30) Umezawa, K.; T. Hori, H. Tajima, M. Imoto, K. Isshiki \& T. TaKeuchi: Inhibition of epidermal growth factor-induced DNA synthesis by tyrosine kinase inhibitors. FEBS Lett. 260: 198 200, 1990

31) Honma, Y; J. Okabe-Kado, R. Kasukabe, M. Hozumi \& K. Umezawa: Inhibition of abl oncogene tyrosine kinase induces erythroid differentiation of human myelogenous leukemia K562 cells. Jpn. J. Cancer Res. 81: $1132 \sim 1136,1990$

32) Oikawa, T.; M. Shimamura, H. Ashino, I. Morita, S. Murota, J. Abe, Y. Nishit \& T. Tominaga: A novel vitamin $\mathrm{D}_{3}$ analogue with an antiangiogenic action. Drug News Perspect, in press 